\title{
The 8 July 2002 storm over Athens: analysis of the Kifissos River/Canal overflows
}

\author{
K. Mazi and A. D. Koussis \\ Institute for Environmental Research \& Sustainable Development, National Observatory of Athens, GR-15236 Palaia Penteli, \\ Athens, Greece
}

Received: 2 November 2005 - Revised: 14 December 2005 - Accepted: 6 February 2006 - Published: 18 April 2006

\begin{abstract}
We analyse the flood event of 8 July 2002 that caused overflows over portions of the lower reach of the Kifissos River/Canal. The storm covered only the lower basin area and was concentrated on the centre and the southwest side of Greater Athens. The issue that stirred the public opinion was whether the hydraulic works underway in lower Kifissos at that time were responsible for the overflows. We explore this issue with the hydrologic-hydraulic model of the Kifissos basin TELESIM. To shed light on the probable cause of the observed flooding, we ran TELESIM for two rain-field scenarios derived from the recorded point-rainfalls, computing flows for each scenario. Depth profiles for channel conditions without obstructions do not explain the observed flooding. With the channel taken as locally obstructed by flow-area reducing ramps plus bed-debris, estimated nominal overflows (bank-full level is threshold, but the water stays inside the channel) compare well with actual ones for the milder rainfall scenario. Hence, the simulations support as plausible the hypothesis that flow obstructions due to the construction caused the overflows.
\end{abstract}

\section{Introduction}

The rapid expansion of the metropolitan area of Athens (population increase: $\sim 1.4$ million (1950), $\sim 3.7$ million (2000)), with the attendant sealing of the soil surface, has reduced the opportunity for rainfall infiltration and enhanced the runoff potential. As a consequence, the city has become increasingly vulnerable to flooding. Several incidents of severe flooding occurred in the 1990's. In preparation for the 2004 Olympic games, the Greek administration took drastic measures to handle the difficult traffic conditions in the metro-complex. One such measure affected the Kifissos River/Canal that drains most of the Athens Basin containing the City of Athens and most adjacent municipalities. A

Correspondence to: A. D. Koussis

(akoussis@env.meteo.noa.gr) highway was constructed over the lower reach of Kifissos, transforming it to a closed channel (a pipe) for about $10 \mathrm{~km}$.

We analyse the flood event of 8 July 2002 that was generated by the most severe storm that occurred over the Athens Basin in the summer of 2002. That storm caused not only street flooding locally, but also, importantly, overflows over portions of the lower reach of Kifissos. Whether the hydraulic works underway in lower Kifissos at that time were responsible for the overflows stirred the Greek public opinion and stimulated a debate in the engineering community. The system conditions were uncertain with respect to the channel geometry (possible flow obstruction) and the rain field, therefore, a forensic-type analysis of the system behaviour was required. This was undertaken with the calibrated/validated hydrologic-hydraulic model of the Kifissos river basin TELESIM (Koussis et al., 2003).

\section{The physical system}

The Athens Basin $\left(430 \mathrm{~km}^{2}\right)$ is surrounded by the mountains Parnis (1400 m) to the north, Pentelikon (or Penteli) (1100 m) to the northeast, Hymettos $(1000 \mathrm{~m})$ to the east and Aigaleo $(400 \mathrm{~m})$ to the west; it also includes several hills (200-300 m) and drains to the sea by the largely canalised streams Kifissos and Ilissos. Our study concerns the Kifissos River Basin shown in Fig. 1, a compactly shaped, $372-\mathrm{km}^{2}$, highly urbanised basin located in moderate to steep terrain. Hydraulic works have been carried out in Kifissos itself since 1900, mostly in the $10 \mathrm{~km}$ closest to the sea (and later in certain of its main tributaries near their confluences with Kifissos); in that reach Kifissos is an artificial channel with no floodplains. The hydraulic works that were concluded in 2004 started in 1972 and were constructed based on a study of 1971 (Sarros, 2004). But these works do not comprise a coordinated flood control system because they have been constructed in response to specific road transportation needs. The latest and most radical intervention was the construction of a highway on top of the last $\sim 10 \mathrm{~km}$ of Kifissos. 

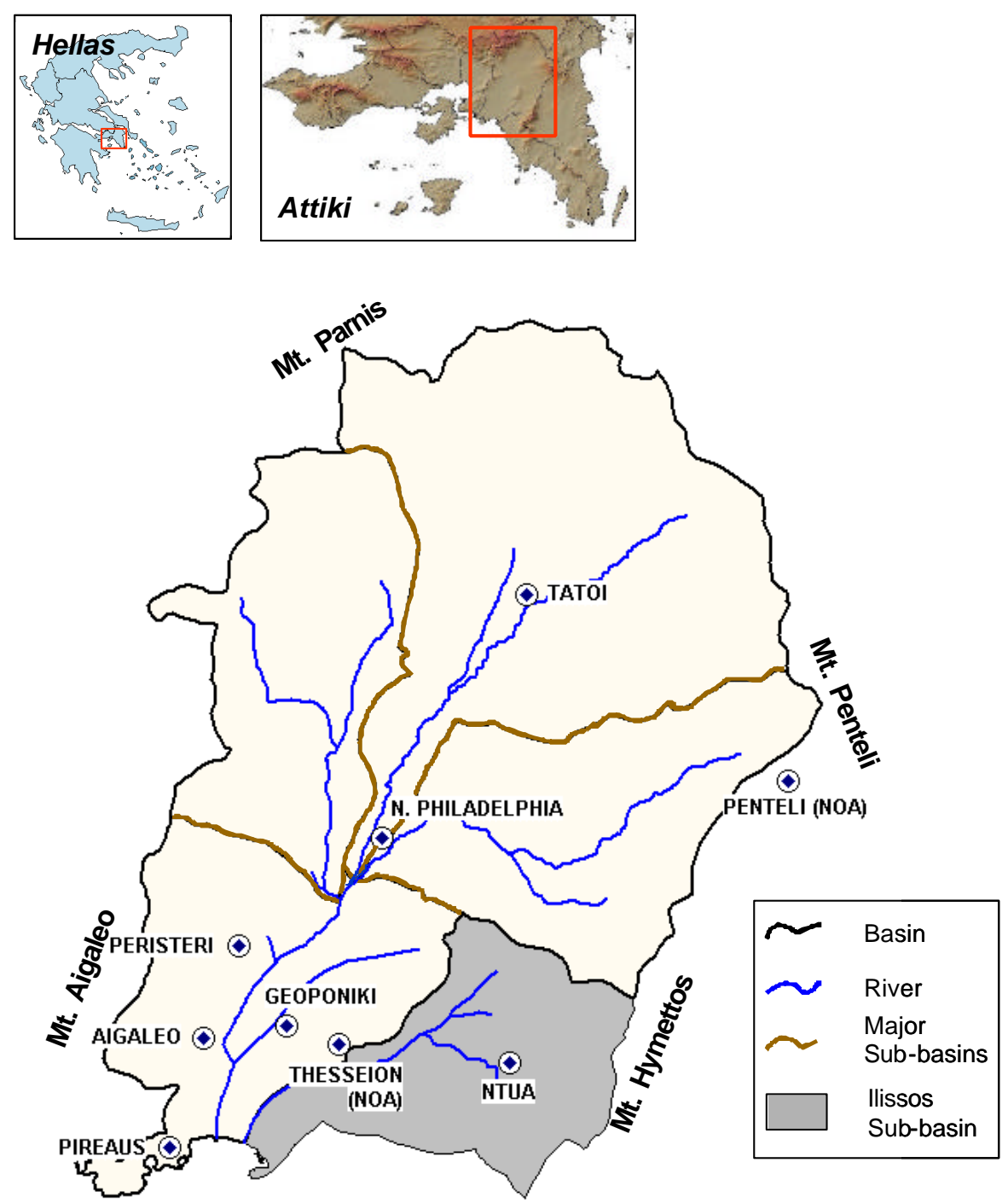

Fig. 1. Athens Basin and rainfall stations.

\section{The flow model}

The analysis is performed with the hydrologic-hydraulic model TELESIM (Koussis et al., 2003) of the Kifissos basin that models explicitly $22 \mathrm{~km}$ (13 km through densely populated areas) of the Kifissos River/Canal. The model considers 11 major streams and sub-basins explicitly, dividing the basin according to topography and land use in $50\left(208.5 \mathrm{~km}^{2}\right)$ natural sub-basins and 46 sub-basins $\left(163 \mathrm{~km}^{2}\right)$ with engineered storm drainage network. The engineered storm drainage system is not modelled in the detail of trunk lines; rather, a lumped approach provides the flows to the streams. The storm flows are routed through the main channels. Water levels are calculated for stream reaches where the geometry is specified; these are the Kifissos Channel and the reaches of its main tributaries near the sub-basins outlets. The Prophitis Daniel Canal, which drains the Athens Centre, also receiving its combined sewer overflows, has been treated in detail because it experienced overflows in the summer of 2002. To evaluate these, we added to TELESIM a hydraulic model of the Prophitis Daniel Canal, after the completion of the TELEFLEUR project (Koussis, 2001).

TELESIM was calibrated and verified with data collected by the hydrometric network established during the TELEFLEUR project, consisting of 8 flow-metering stations installed in Kifissos and near the outlets of its major sub-basins. These monitoring stations measured water level and velocity, calculated flow rate and logged the data. Velocity was measured with one or two pairs of acoustic sensors, depending on water level. The complete flow-monitoring network operated only during the TELEFLEUR project and much of it was dismantled after 2001. Therefore few hard data exist for the flood events of the summer of 2002.

Nevertheless, the issue of whether the hydraulic works underway in lower Kifissos at that time caused the overflows could still be explored through a hydrologic-hydraulic analysis of the system with TELESIM. The analysis compares 


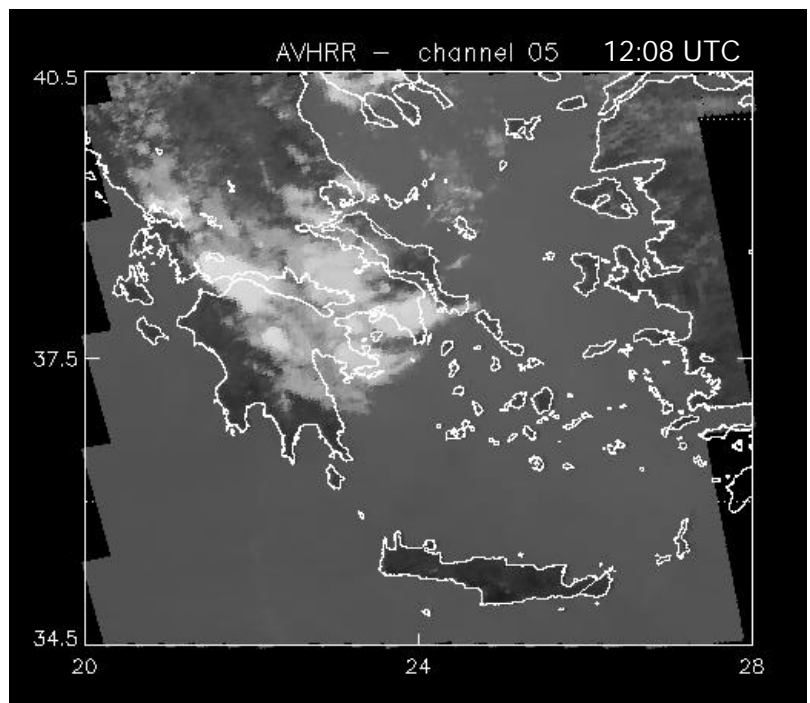

Fig. 2. Image from the NOAA satellite N16 - AVHRR, $\lambda=11.5-$ $12.5 \mu \mathrm{m}$.

the overflow thresholds in a flow-obstructed channel with the pre-construction, regular flow conditions, for the same rainfall derived from two rain field scenarios. This engineering study sheds light on the probable causes for the observed flooding, on the basis of quantitative estimates, derived from a rational approach that also considered uncertainties in the field.

\section{The storm of 8 July 2002}

From the data of Table 1 and the map of Fig. 1, it is evident that the storm covered only the lower quarter of the basin and was concentrated on the centre and the southwest side of the city. The mean density of rain gauges is $\sim 15 \mathrm{~km}^{2} /$ gauge in the lower $30 \%$ of the basin. Composite hyetographs for the distributed runoff computations were prepared from the recorded point-rainfall via Thiessen polygon weighting. Instability of the lower atmosphere induced the 8 July 2002 storm. Figure 2 was created from observations of an AVHRR sensor on board the NOAA satellite N16; it shows the cloud coverage at channel $5, \lambda=11.5-12.5 \mu \mathrm{m}$, a far infrared wavelength. In that image, taken over Athens at 12:08 UTC, white pixels correspond to cold cloud top (clouds with high vertical extension such as thunderclouds). According to information from a network of amateur weather observers communicated over the Internet, rain mixed with hale fell at various locations sporadically. That storm was intense (e.g., of the total depth of $94.6 \mathrm{~mm}$ recorded at the Agricultural University of Athens, located near the City Centre, $67 \mathrm{~mm}$ (71\%) fell in one hour (Fig. 3)), but cannot be characterised as extreme based on the total storm depths.

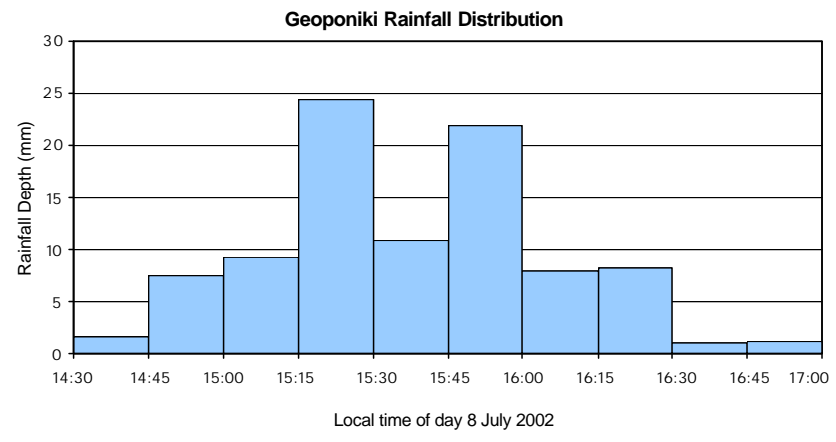

Fig. 3. Rainfall distribution at Geoponiki Station, near the Athens City Centre.

\section{The flood of 8 July 2002}

Along with a basin's physical characteristics, a storm's extent, location, intensity and duration are determinant factors of the runoff. Based on the above storm data, besides the documented phenomena of local street flooding, e.g. in the City Centre, the observed high flows in the Prophitis Daniel Channel are expected. In contrast, flows should be low in the major tributaries of Kifissos, Podoniftis and Eschatia/Fleva, more so in the former, as the latter carries also the flow of the Michelis Stream that drains the area of Petroupoli in the southwest part of basin, entering the Fleva Channel just upstream of its confluence with Kifissos (locations shown in the schematic of Fig. 4). Consequently, the flows in Kifissos upstream of km-station 9+000 should be rather low. The problem is thus framed as follows: Are the storm drainage inputs downstream of $\sim 9 \mathrm{~km}$, mainly of the streams Maska (km-station 6+320), Nikaia (km-station 2+796) and Prophitis Daniel (km-station 2+300), sufficiently large and timed such as to cause the overflow of lower Kifissos, had the channel not been obstructed by the construction activities in the reach? And if not, what reduction of the cross-sectional area causes overflow?

\section{The simulations of the Kifissos flood of 8 July 2002}

TELESIM generates runoff from natural areas via the Curve Number method of the US Soil Conservation Service (SCS, 1985 ) and from sealed areas via the concept of discharge coefficients. Then, a flow routing procedure, based on a series of linear reservoirs, determines the discharges along the channels (Pilgrim and Cordery, 1992). Flood stage profiles are calculated by the standard-step method (e.g. Henderson, 1966), treating the flow at each time step as quasi-steady, with the mean of the in- and outflow in each channel segment as discharge at every time level. Since the channel discharges are calculated prior to, and thus independently of the depth profiles, no provision for loss of overflowing water is made. Overflow is indicated by a higher than bank-full stage in a section with fictitious vertical sides above bank-full level and is thus nominal. The water is retained inside the channel at 
Table 1. Areal rainfall distribution of the storm of 8 July 2002.

\begin{tabular}{llcl}
\hline Station Name & Organisation & Storm Depth $(\mathrm{mm})$ & Location \\
\hline Geoponiki & Agricultural University & 94.6 & City Centre \\
NOA-Thesseion & Natl. Observatory Athens & 91.2 & City Centre \\
Peristeri & M-EPP \& PW & 62.5 & Southwest \\
Aigaleo & M-EPP \& PW & 105 & South-Southwest \\
Pireaus & Natl. Meteo. Service & 22 & South* \\
Nea Philadelphia & Natl. Meteo. Service & 2.3 & Centre of basin \\
Zografos & Natl. Tech. Univ. Athens & 37.8 & East* \\
NOA-Penteli & Natl. Observatory Athens & 7.8 & Northeast* \\
Tatoi & Natl. Meteo. Service & 0.4 & North \\
\hline
\end{tabular}

${ }^{1}$ Ministry for the Environment, Physical Planning \& Public Works; ${ }^{*}$ slightly outside of the basin.

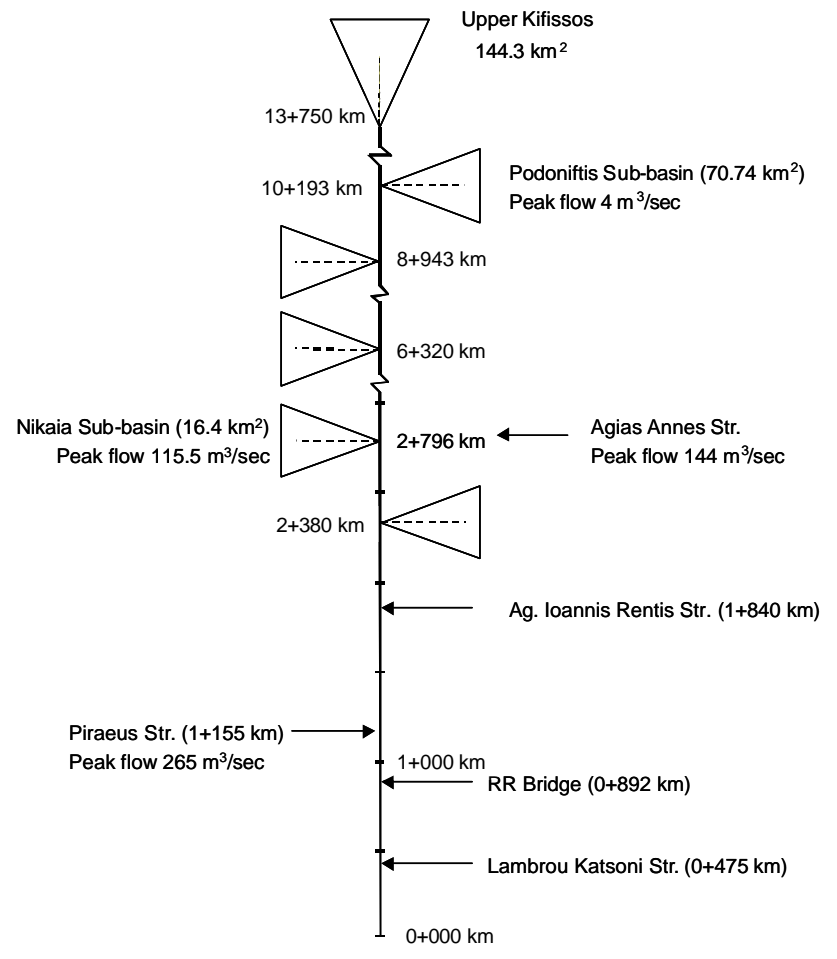

Fig. 4. Schematic of the Kifissos drainage network and calculated peak outflows from the sub-basins for Rainfall Scenario 1.

all times; downstream flows are thus overestimated. Hence, if no overflow is predicted downstream, it is unlikely that it could actually occur; conversely, if an overflow did occur downstream, the reason for it should be investigated further.

To test the uncertainty from a possible under-representation of the true rain field by the rainfall synthesised by the Thiessen polygons, we varied the timing of the rain at the Aigaleo gauge, where only the total storm depth was measured. This is the largest rain recorded and determinant for the runoff from the Nikaia sub-basin. We considered two rain distribution scenarios: (i) synchronous with the Peristeri station and (ii) synchronous with the Geoponiki sta-

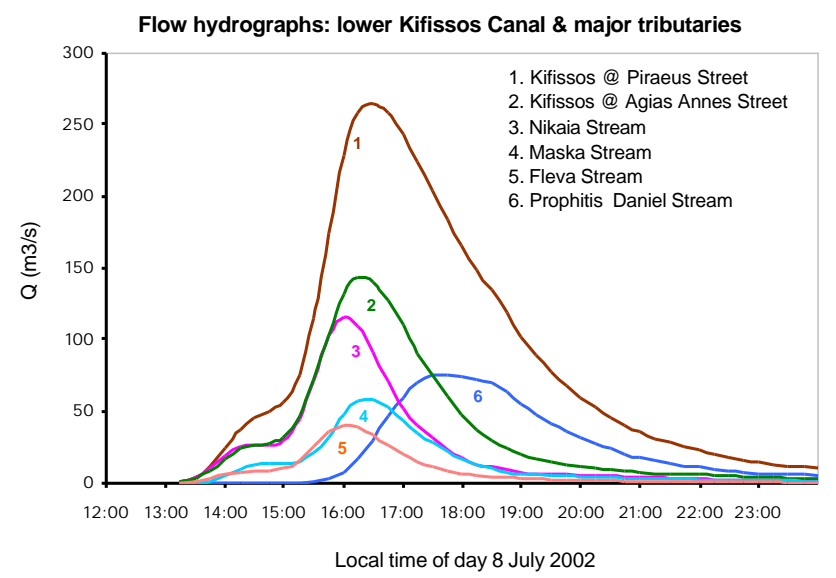

Fig. 5. Rainfall Scenario 1: Simulated flows in the Kifissos River and its tributaries.

tion. Scenario 1 did not produce overflow anywhere along the lower Kifissos (as described below, there was overflow in the Prophitis Daniel tributary, but that sub-basin's runoff is not affected by the rainfall at the Aigaleo gauge); the flow at the Piraeus Street Bridge peaked at $265 \mathrm{~m}^{3} / \mathrm{s}$. With the rainfall of Scenario 2, the peak flow at the Piraeus Street Bridge increased to $300 \mathrm{~m}^{3} / \mathrm{s}$, but created only an isolated, marginal overflow there; nowhere else did the lower Kifissos Canal flood. These results give credence to the flow-obstruction thesis that we pursue further with the milder rain Scenario 1 below, to underscore the strength of this hypothesis.

Figure 5 shows the simulated flows for rainfall Scenario 1. At Agias Annes Street Bridge, km-station 2+790, the peak flow rate was only $144 \mathrm{~m}^{3} / \mathrm{s}$, as the upstream sub-basins contributed expectedly little to the flood (Fleva $40 \mathrm{~m}^{3} / \mathrm{s}$, mostly flow of Michelis, $32.5 \mathrm{~m}^{3} / \mathrm{s}$; Maska $58 \mathrm{~m}^{3} / \mathrm{s}$ ). In contrast, significant were the peak flows of the streams of Nikaia and of Prophitis Daniel at $115.5 \mathrm{~m}^{3} / \mathrm{s}$ and $75.5 \mathrm{~m}^{3} / \mathrm{s}$, respectively, both entering Kifissos downstream of the Agias Annes Street Bridge. At the Piraeus Street Bridge the flow peaked at $265 \mathrm{~m}^{3} / \mathrm{s}$. 
The hydraulic simulations confirmed the observed overflow of the Prophitis Daniel Channel (Fig. 6a); the water level exceeded the height of the banks over $\sim 565 \mathrm{~m}$, starting $\sim 760 \mathrm{~m}$ from its confluence with Kifissos. Cause for the overflow is a constriction at $\mathrm{km}$-station $0+763$, where an oblique $1 \mathrm{~m}$-high wall reduces the channel width by $\sim 80 \%$ within $10 \mathrm{~m}$ and the downstream channel is split in two sections by a flow-aligned wall over $\sim 40 \mathrm{~m}$. According to a rough hydraulic estimation, this constriction reduces the flow conveying capacity of the Prophitis Daniel Channel to $\sim 45 \mathrm{~m}^{3} / \mathrm{s}$ (compared to $\sim 70 \mathrm{~m}^{3} / \mathrm{s}$ without constriction). There is thus a certain computational excess flow to Kifissos, but it does not affect the peak flow downstream because of the timing of the hydrographs (see Fig. 5).

Depth profiles computed for the unobstructed Kifissos channel (cross-sections updated for that stage of construction) show the stages remaining throughout below bank-full level; the highest watermark is $3 \mathrm{~cm}$ clear of the banks immediately upstream of the Piraeus Street Bridge, at km-station 1+116. Previous hydraulic design studies have shown that the flow-conveying capacities at the old bridges across Kifissos were far less than the upstream channel's; for example, the old metal Piraeus Street Bridge could convey almost $300 \mathrm{~m}^{3} / \mathrm{s}$, about half as much as its upstream channel (before its widening) for $\sim 1 \mathrm{~km}$. Under these circumstances, the model-estimated $265 \mathrm{~m}^{3} / \mathrm{s}$ cannot explain the observed extensive overflows (and, as we saw, neither can the more intense rainfall Scenario 2).

The observed overflows should therefore be attributed to flow obstruction in the Kifissos channel. Such obstructions could have been caused by debris from the then-ongoing construction works in the last $3 \mathrm{~km}$ of Kifissos and from access ramps inside the channel, for the trucks and for the earthmoving equipment. Construction debris and ramps were visible in the channel of Kifissos at that time and overflows were reported over the reach from $\mathrm{km}$-station 0+475 (Lambros Katsonis Bridge) to km-station 2+280, at the north edge of the Rentis Produce Market near the entry of the Prophitis Daniel stream (see the schematic of Fig. 4). We explore these issues, using again the first rain scenario, by raising the channel bed by $0.1 \mathrm{~m}$ from $\mathrm{km}$-station $0+750$ to $\mathrm{km}$-station $2+300$, immediately downstream of the Prophitis Daniel Kifissos confluence, and by lateral constrictions at four sections.

This modelling approach is approximate. First, it considers the debris to remain attached to the channel bed, when, in fact, the floodwaters eroded some loose material (but the actual debris thickness was more than $10 \mathrm{~cm}$, and, in addition, the presence of suspended load in the water column increases flow resistance). Second, the lateral obstructions were modelled as four one-sided restrictions, representing isolated ramps, with dimensions height $3 \mathrm{~m}$, width $5 \mathrm{~m}$ and length $50 \mathrm{~m}$. These simplified representations notwithstanding, the computed water level profiles shown in Fig. 6b give clear indication of the flow blockage required to rationally explain the overflows observed along the riverfront of the Produce Market at Rentis (from the RR Bridge to the Bridge
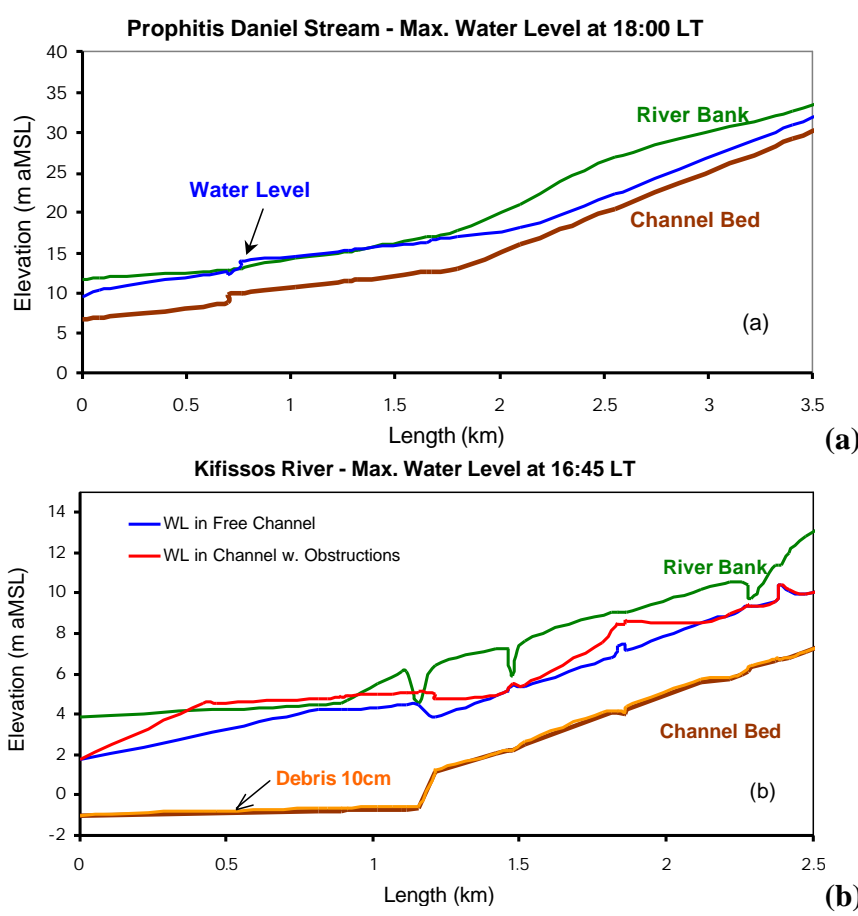

(b)

Fig. 6. (a) Simulated water levels for Prophitis Daniel Stream; (b) Simulated water levels in Kifissos, for unobstructed flow and for obstructed flow.

of Agios Ioannis Street), in the vicinity of the Piraeus Street Bridge, the three bridges around $\mathrm{km}$-station 0+900 and in the area of the Lambros Katsonis Bridge near km-station 0+500 (for locations, see again the schematic in Fig. 4).

\section{Conclusions}

The goal of this study was to contribute to the scientific debate about the causes of an event that attracted public attention, and not to model the flooding conditions in Kifissos on 8 July 2002 exactly. Modelling was used as a forensics tool to screen probable from unlikely interpretations of the flood event. In that sense, the presented flow analysis showed that the flows generated from the recorded rainfall, which was synthesised in two different input scenarios for the rainfallrunoff simulations, were not sufficient to cause overflow of the unobstructed Kifissos Canal (except for a marginal overflow at a single cross-section, when the rainfall was artificially intensified). In contrast, the TELESIM analysis reproduced qualitatively the observed phenomena of flooding in the lower Kifissos Basin on the basis of a plausible rainfall scenario and reasonable restrictions (in size and distribution) of the channel from the then ongoing construction: the simulations confirm the overflow of the Prophitis Daniel stream and the extensive overflows of Kifissos in the reach between $\mathrm{km}$-stations $0+500$ and 2+000. 
Acknowledgements. The authors acknowledge the support of the Directorate-General Information Society Technology of the European Commission, under contract EN 4003 TELEFLEUR, and of the General Secretariat for Research \& Technology, Hellenic Ministry for Development.

Edited by: V. Kotroni and K. Lagouvardos

Reviewed by: anonymous referee

\section{References}

Henderson, F. M.: Open Channel Flow, Macmillan Pub. Co., New York, N.Y, 1966.

Koussis, A. D.: Final Report TELEFLEUR, 30 p. and Appendices 45 p., Athens, Greece, 2001.
Koussis, A. D., Lagouvardos, K., Mazi, K., Kotroni, V., Sitzmann, D., Lang, J., Zaiss, H., Buzzi, A., and Malguzzi, P.: Flood forecasts for an urban basin with integrated hydro-meteorological model, J. Hydrologic Engineering, 8, 1, 1-11, 2003.

Pilgrim, D. H. and Cordery, I.: Handbook of Hydrology, Chapter 9: Flood runoff, edited by: Maidment, D. R., Mc Graw-Hill, New York, 1992.

Sarros, M.: Flood protection of the Athens basin (Kifissos-Ilissos), presentation (in Greek) at the Meeting "Flood Protection of Attica", organised by the Technical Chamber of Greece, Athens, 2004.

U.S. Soil Conservation Service: National Engineering Handbook, Section 4: Hydrology, U.S. Department of Agriculture, Washington, D.C., 1985. 